\title{
The Algebraic Thinking Process in Solving Hots Questions Reviewed from Student Achievement Motivation
}

\author{
Windia Hadi ${ }^{1}$, Ayu Faradillah ${ }^{2}$ \\ ${ }^{1,2}$ Muhammadiyah Prof. DR. HAMKA University, Indonesia \\ Corresponding author: windia.hadi@uhamka.ac.id
}

\begin{abstract}
This research is a preliminary study that aims to describe the algebraic thinking process of prospective mathematics teachers. This research is a qualitative descriptive study. Subjects were grouped into two categories based on high and low achievement motivation. Data is obtained based on the results of tests conducted in the algebra process. Research subjects (S1) and (S2) with high achievement motivation and subjects (S3) and (S4) with low achievement motivation using different algebraic thought processes. Subjects (S1) are able in the process of thinking algebra until crashing indicators assess understanding with understanding of the concept wrong in solving Higher Order Thinking Skills (HOTS) problems, whereas, (S2) the process of thinking algebra is only capable of chunking information (pieces of information), (S3) able in the process of thinking algebra until indicators of change with wrong answers, and the subject (S4) is able in the process of thinking algebra only until chunking information (pieces of information). Factors that cause subjects S1, S2, S3, and S4 are still unable to solve HOTS questions in algebraic thinking processes are questions of knowledge on HOTS material and difficulty understanding concepts in working on algebra need special handling in improving understanding of concepts in algebra.
\end{abstract}

Keyword: Algebra; Achievement Motivation; HOTS.

\section{INTRODUCTION}

Higher-order thinking skills (HOTS) are a type of non-algorithmic thinking (i.e analytical, evaluative and creative thinking) involving metacognition (Samo, Darhim, \& Kartasasmita, 2017). It is a high-level mathematical thinking ability, which is a basic ability that must be developed in mathematics learning. Prospective mathematics teachers need to develop the extent of mathematical thinking ability in solving HOTS problems. Based on research (Maharaj \& Wagh, 2016) suggest getting used to and practicing HOTS questions among students so that HOTS thinking patterns are no longer something new but must be used to be done in the learning process in the classroom. The test instrument or commonly called a question is one of the measuring instruments used to detect students' algebraic thought processes. Most of them solve a mathematical problem by using algebra, especially the HOTS problem. Algebra is very important in mathematics (Malihatuddarojah \& Prahmana, 2019; Ojose, 2011; Star et al., 2015). Algebra is taught from elementary school through colleges such as analytic geometry, calculus, statistics, trigonometry, and topology (Jupri et al, 2014; Makonye\& Stepwell, 2016). Also, all the activities that humans do every day are thinking. Thinking involves the process of manipulating information mentally, such as forming abstract concepts, solving various problems, making decisions and making reflective, critical or generating creative ideas (Jupri, Drijvers, \& van den Heuvel-Panhuizen, 2014).

Mathematics is inseparable from thinking, so one of the thoughts that are often done when students learning mathematics is algebraic thinking (Cahyaningtyas, Novita, \& Toto 2018). Algebra thinking is a tool for learning mathematics, especially in learning algebraic mathematics and processes in students on generalizing mathematical ideas or ideas from an 
example so that in compiling these generalizations expressed through writing or conversation (argumentation) followed by expressing them according to age level (Blanton \& Kaput, 2011; Kamol \& Har, 2010). Someone who does the algebraic thought process in learning mathematics is usually characterized by the use of symbols that are representations to resolve quantitative situations relationally by using symbols (Andriani, 2015). Therefore, prospective mathematics teachers need to explore the emergence of algebraic thinking, understand how students think and its characteristics, understand how to reason algebraically and its development. By knowing students' algebraic thinking processes, the teacher can (1) track the location and type of mistakes made by students, and (2) find out the thinking errors that occur and tidy up the student's knowledge network. Previous research discusses more students' mistakes in algebra at Junior High School. Research (Jupri et al., 2014; Malihatuddarojah \& Prahmana, 2019) shows that students in Indonesia make mistakes in solving problems about algebraic operations such as errors in variables, errors in negative signs, errors in completing algebraic equations, errors in operating algebraic forms and errors in solving fractions. Other research (Cahyaningtyas et al., 2018) found that students often had difficulty in obtaining information from the questions given so students had difficulty predicting patterns and information chunking. What distinguishes it from other research is that researchers are interested in analyzing several algebraic thought processes of a prospective mathematics teacher in terms of student achievement motivation. Thus, the results of this study are expected to be able to show and describe various algebraic thinking processes in terms of student achievement motivation. This research will analyze the extent to which students' algebraic thinking processes in solving HOTS problems because students are future teachers to create students who can develop mathematical thinking skills.

Also, according to (Gais \& Afriansyah, 2017) many factors cause students to still be mistaken in working on HOTS questions, namely the process that is passed during learning is not optimal, lack of understanding of the questions, incompleteness in reading questions, lack of attention from parents and student achievement motivation. Student achievement motivation is one of the success factors in solving HOTS problems. Based on the results of research (Sarangi, 2015) In today's complex world certain educational qualifications do not guarantee success in life. To be a successful human being, everyone needs an environment conducive to human touch for sustainable and successful growth. Therefore, the role Achievement motivation for higher academic achievement is not only important (Kamaei \& Weisani, 2013) research concluded that people with high achievement motivation generally tend to expect, pride, anticipation, and pleasure but people with low achievement motivation generally avoid emotions, such as anxiety, fear and failure defense. According to (Taskesen, 2019) achievement motivation is the drive of individuals to direct themselves to the reaction to achieve the best goals and results based on standards of excellence and be able to arouse, direct and maintain one's behavior and regulate one's behavior in starting a task to the end and maintaining it from time to time. Someone who is considered to have achievement motivation if they have the desire to do something work and achievement that is better than others. Characteristics of individuals who have high achievement motivation have a standard of achievement, prefer to work in situations when someone gets feedback, do not like the success that is not accidental or because of the actions of others and prefer to work on tasks that are of medium difficulty and realistic 
level in achieving the aim. Many previous studies have only examined the difficulties of students in solving hots problems in algebraic thinking skills, but no focus examines students' achievement motivation in solving hots problems, this is a gap in this study.

\section{THE RESEARCH METHODS}

This research is a qualitative case study. This study aims to describe the algebraic thinking process of students in solving HOTS questions based on student achievement motivation. Data collected in this research is in the form of qualitative. Data was obtained based on the results of grouping low and high student achievement motivation, then two high achievement motivation subjects and two small motivation subjects were taken; then four items were given HOTS questions and test sheets. Data collection instruments used in this study were questionnaires and test instruments. The questionnaire instrument was used to determine low and high student achievement motivation. The student achievement motivation tool contains responses by choosing a scale between 1-4 with the statement Always, Frequently, Rarely and never with 28 comments that have been validated by Lecturers at the Indonesian University of Education. HOTS instruments were obtained from the ONMIPA problem with a slight modification by researchers. Indicators used to see students' algebraic thought processes are presented in Table 1.(Driscoll et al., 2001)

Table1. Indicators of Algebra Thinking Process

\begin{tabular}{ll}
\hline \multicolumn{1}{c}{ Indikator } & \multicolumn{1}{c}{ Deskripsi } \\
\hline $\begin{array}{l}\text { Classifying } \\
\text { Information }\end{array}$ & $\begin{array}{l}\text { Thinking is characterized by the ability to organize information in a way } \\
\text { that is useful for expressing patterns, relationships, and decisive rules }\end{array}$ \\
Chunking Information & $\begin{array}{l}\text { Thinking is characterized by proficiency in seeking repetition of pieces } \\
\text { of information that reveal how a pattern works }\end{array}$ \\
Predict the Pattern & $\begin{array}{l}\text { Thinking is characterized by the ability to find and understand the order } \\
\text { in certain situations }\end{array}$ \\
Describe the Rules & $\begin{array}{l}\text { Thinking is characterized by the ability to describe procedural or } \\
\text { regulatory steps explicitly or recursively without specific input }\end{array}$ \\
$\begin{array}{l}\text { Different } \\
\text { representations }\end{array}$ & $\begin{array}{l}\text { Thinking is characterized by the ability to think and try to represent } \\
\text { different problems to find different information about the problem }\end{array}$ \\
Drawing changes & $\begin{array}{l}\text { Thinking is characterized by the ability to describe changes in a process } \\
\text { or relationship explicitly as functional relationships between variables }\end{array}$ \\
Justify the rules & $\begin{array}{l}\text { Thinking is characterized by the ability to justify why a rule works for } \\
\text { several people. }\end{array}$ \\
\hline
\end{tabular}

From this criterion indicator, if the subject follows all the indicators of the algebraic thought process, it can be interpreted that the item has a complete algebraic thought process. If some procedures are incorrect, then the subject has a very poor algebraic thought process. This test is for two students' high achievement motivation and two students' low achievement motivation. Interviews in this study are interviewing the subject based on the written results of the questions presented, aiming to clarify the subject's written answers and to obtain 


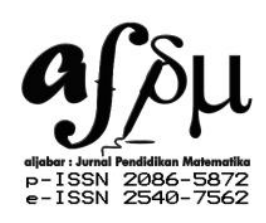

information about the causes of students doing the answers. Interview guidelines are not structured because researchers do not use interview guidelines that have been arranged as a whole and systematically to collect data, but interview guides that users only in the form of an outline of the problem to be asked (Sugiyono, 2010). Questions asked by researchers do not have to be the same for each subject but depend on the amount of information needed by the researcher. Before the researcher conducts the analysis, the researcher checks the validity of the data using time triangulation to obtain valid data. Furthermore, the data is accurately analyzed and conclusions are drawn.

\section{THE RESULTS OF THE RESEARCH AND THE DISCUSSION}

Two students with high achievement motivation and two students with low motivation were given explanatory questions related to solving HOTS questions with indicators in accordance with the algebraic thinking process. Students are not allowed to open books and mobile phones while working on the questions. Students are given 60 minutes to complete the test and 40 minutes to interview. The following is one example of the questions given to prospective mathematics teacher students, namely:

1. Known :

$$
\begin{gathered}
a+2 b=1 \\
b+2 c=2 \\
b \neq 0
\end{gathered}
$$

If $+n b+2018 c=2019$, then determine the value $n$.

2. If $=\frac{\sqrt{111}-1}{2}$, then determine the value $\left(2 x^{5}+2 x^{4}-53 x^{3}-57 x+54\right)^{2019}$.

3. Determine all positive real numbers $(x, y, z)$ that fulfills the equation $x y+y z+z x=27$ and $x^{4}+y^{4}+z^{4}=x y z(x+y+z)$

\section{Figure 1. Presents Statistical Results in Student}

Achievement motivation using data analysis on the Rasch modeling tool. Statistics show the infit and outfit of each respondent and questionnaire items. The results show that the person and items are valid and reliable.

Tabel 2.Instrument Reliability on Student Achievement Motivation

\begin{tabular}{lllll} 
& Mean Logit & Separation & Reliability & Alpha Cronbach \\
\hline Person & 1.70 & 1.73 & 0.75 & 0.88 \\
Item & 0.00 & 5.10 & 0.96 & \\
\hline
\end{tabular}

Classification of student achievement motivation is carried out using the Rasch model. For calibration to be carried out between respondents and test items, student responses to questionnaire statements were processed from raw scores then converted to logit interval values using Rasch modeling. Then export as an excel file. Data were analyzed using Winsteps 3.74.0 software to produce consistent Rasch output (Linacre, 2007). After Rasch's output, the data is divided based on the average value and standard deviation, then two high and low achievement motivation groups are obtained. Next, to analyze the students' algebraic thought process in completing HOTS questions, subjects were taken based on high and low achievement 
motivation of two items respectively. Below is the result of a grouping map of student achievement motivation.

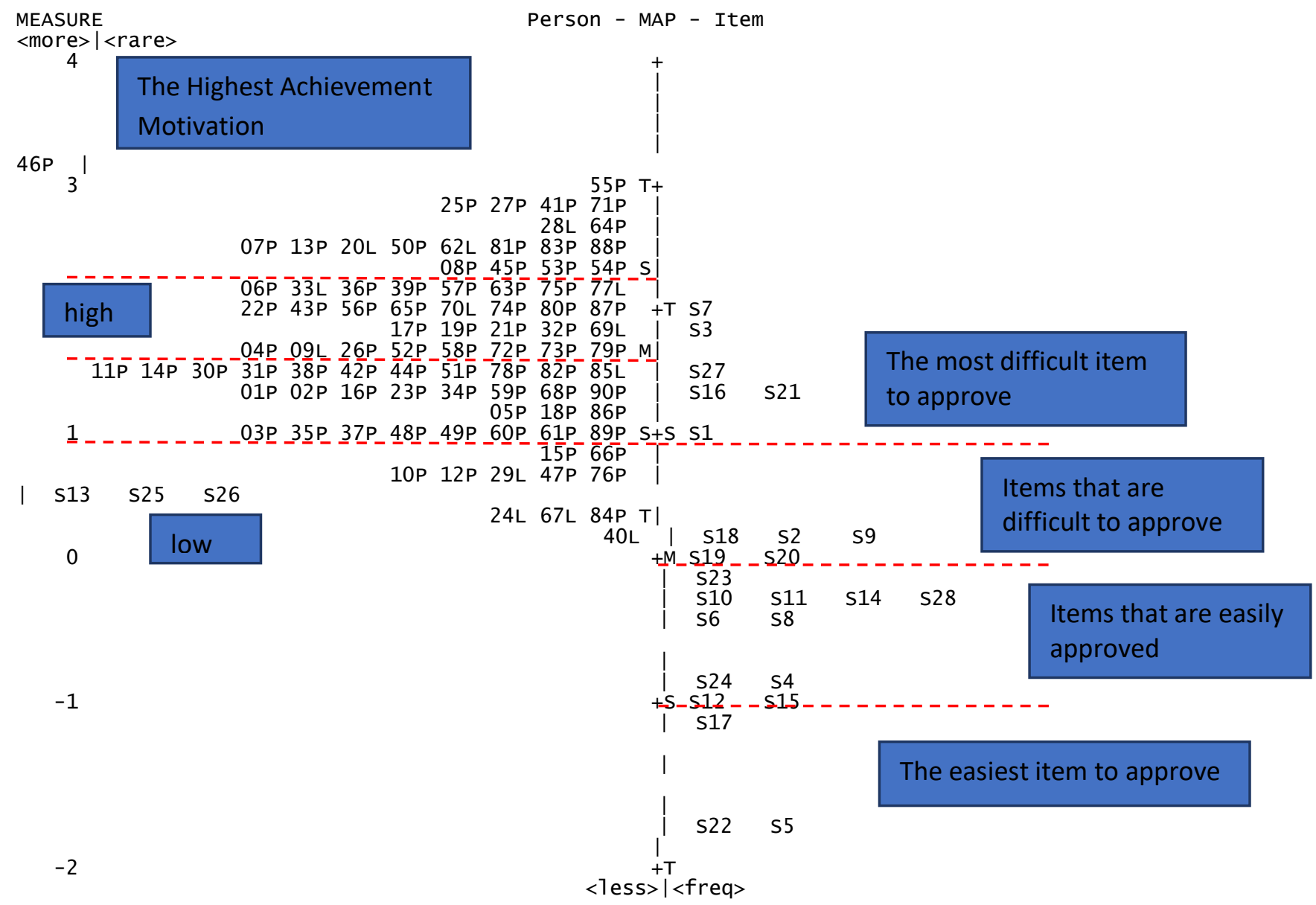

Figure 2. Person-Item Distribution Map on Student Achievement Motivation

In Figure 2. shows 20 students have higher achievement motivation, 29 students have high achievement motivation, 30 students have moderate achievement motivation and 11 students have low achievement motivation, while there are 6 statements that students are very difficult to say always, 8 student statements are difficult say always, 11 easy statements say always and 3 statements that are very easy to say always. In this article only focused on students who have high and low achievement motivation. The randomly selected respondents are $33 \mathrm{~L}$ (S1), 77L (S2), 47P (S3) and 40L (S4). Where S1 and S2 have high achievement motivation, whereas S3 and S4 have low motivation. Subjects S1 and S2 have superior performance better than others while S3 and S4 do not prioritize academic achievement in mathematics. In accordance with the results of (Sarangi, 2015) that achievement motivation increases the academic achievement of students and Achievement Motivation of Prospective Teachers in Gender matters in this study revealed that there was no statistically significant difference between achievement motivation of prospective teachers in terms of gender. It was seen in the literature that several studies stated that the structure of student motivation differed in gender provisions (Taskesen, 2019). Below will be presented the results of students' algebraic thinking 
process in working on HOTS problems in terms of high achievement motivation and low achievement motivation.

\section{Exposure of Analysis Results of Algebra Thinking Process for Prospective Mathematics} Teacher Subjects 1 (S1) and Subject 2 (S2) in terms of High Achievement Motivation

The results of the SI solution in solving the HOTS problem are presented in Figure 3. That is the answer to problem number 1 . The first algebraic thinking process is in accordance with the indicators that have been made namely grouping information. When classifying information, students have written down the information obtained from the questions by writing down.

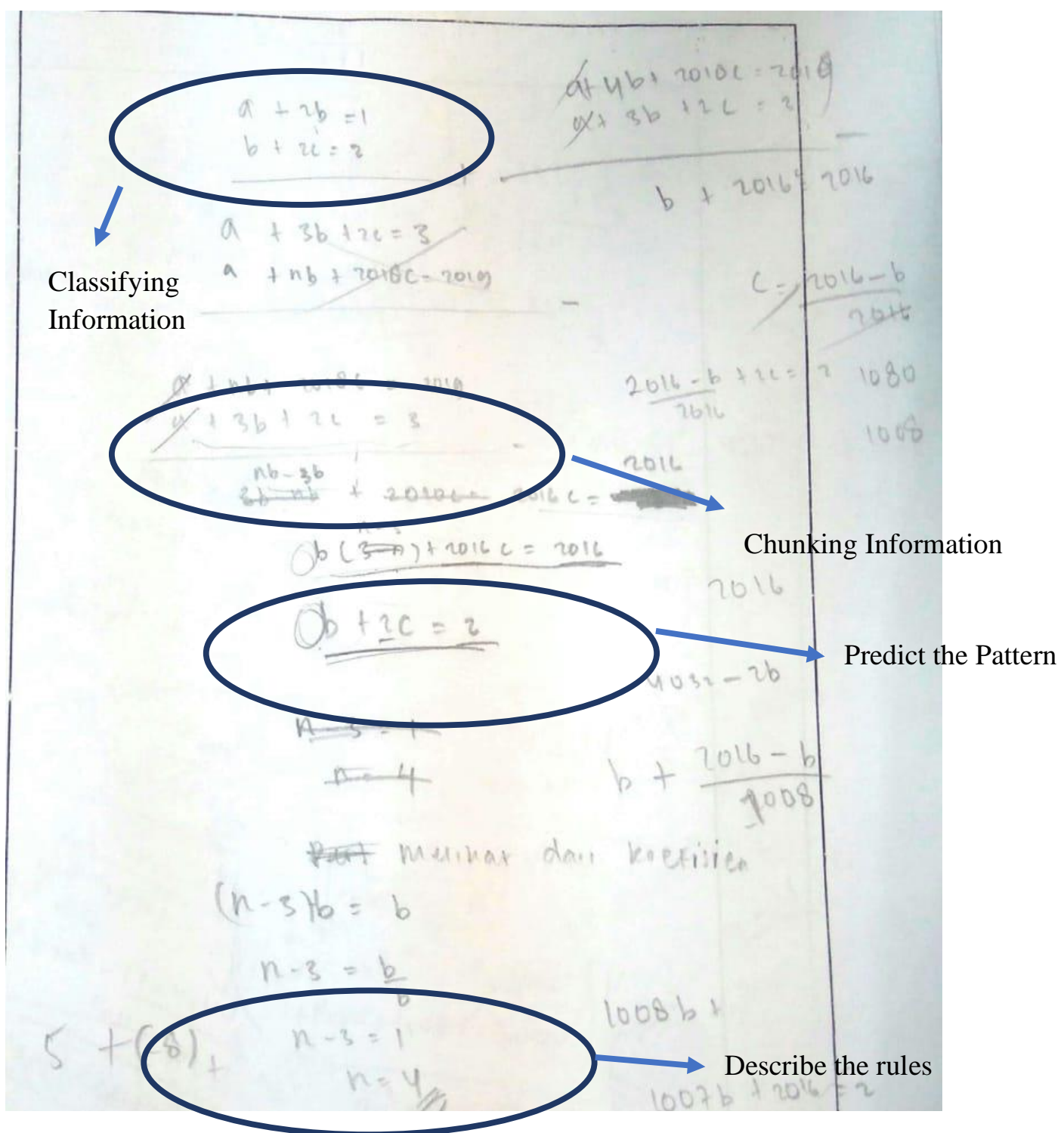

Figure 3. Results of S1 Answers for item number 1

S1 can find pieces of information by linking information that exists beforehand by eliminating known equations, then writing down pieces of information that are asked by eliminating information that is known, then $\mathrm{S} 1$ predicts the pattern of elimination results with known forms 


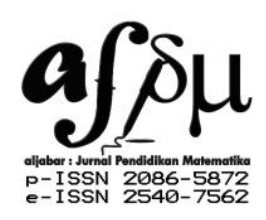

of equations. S1 assumes that $(n-3) b+2016 c=2016$ and $b+2 c=2$ are the same, so S1 answers $\mathrm{n}=4$. This, according to the results of interviews conducted by researchers

Q: Can you explain why you got 4 ?

S1 : I used the elimination method and found that nb minus $3 \mathrm{~b}$ plus $2016 \mathrm{c}$ resulted in 2016

$\mathrm{P} \quad$ : Then after that?

S1 : I use the rules of bu equation, so I have the $b$ factor into factor ( $n-3)$ then value $b$ equal to b, the coefficient is zero. 2016c value is equal to $2 c$, then 2016 is equal to 2 . Now because $n-3$ is equal to 1 then $n$ is 4

$\mathrm{P} \quad$ : Try checking again with the substitution the value of $n$ is 4 , is it in accordance with that asked about?

S1 : a, b and c I can't find it mom

S1 subject is not able to complete the algebraic thought process to the end so that when confirmed confirming the rules, S1 is confused and does not know it. According to Schmittau\& Morris (in Kieran, 2004), developing the ability of students to think divergent (think in a variety of ways) can develop algebraic mastery. The first step is the development of theoretical thinking abilities. For example, developing students' habits in finding relationships between quantities in contextual situations and then learn to solve an equation by paying attention to the structure found. Meanwhile, the results of completing S2 are presented in Figure 4. The algebraic thought process can only be pieces of information without first grouping information from the questions. Furthermore, the algebraic thought process cannot be completed until the end. In accordance with the results of the interview, the S2 did not know the next stage in completing the HOTS problem. The following are the results of the interview with the subject of S2.

Q : What about number 1?

S2 : It's hard, mom.

Q : Where does this get zero from?

S2 : I'm from mom, I put $n$ equal to zero and b equal to 1 so the result is 2019 , so I assume if the value of $n$ is 1 .

Q : Where do you get zero values from?

S2 : I don't know, ma'am.

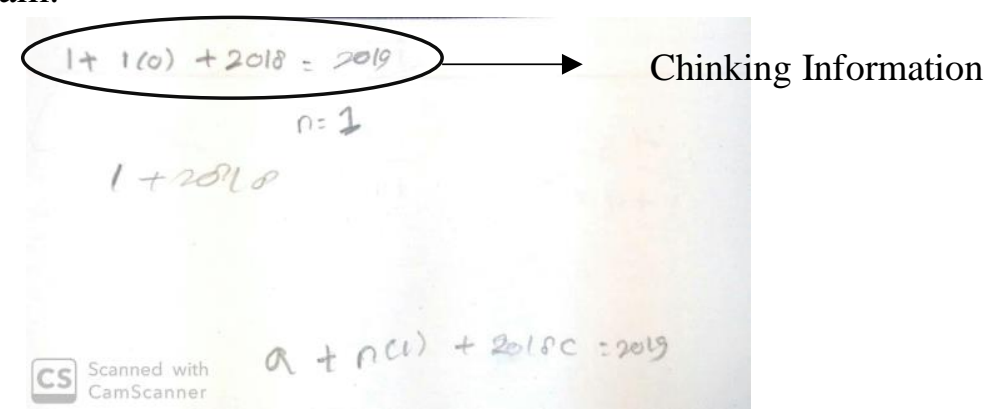

Figure 4. Results of Answer S2 on number 1

Based on the results of the interview it was found that the S2 subject did not know how to solve the HOTS problem, so the algebraic thought process could only provide pieces of 
information and could not continue the process until the last indicator was to justify the rules. It can be said that the subject S2 is not capable of algebraic thought processes. The lack of understanding of the subject S2 to HOTS problems makes the subject S2 can not finish well and looks very algebraic thinking process. This is in accordance with (Booth, Lange, Koedinger, \& Newton, 2013) Making mistakes in writing and operating variables is an indication of a student who lacks understanding of the key variables that constrain his understanding of algebraic concepts.

Exposure of Analysis Results of Algebra Thinking Process for Prospective Mathematics Teacher Subjects 3 (S3) and Subject 4 (S4) in terms of Low Achievement Motivation

The results of the completion of S3 in solving the HOTS problem are presented in Figure 5. That is the answer to problem number 1 . The first algebraic thinking process is in accordance with the indicators that have been made namely grouping information. When classifying information, students have written down the information obtained from the problem by rewriting the problem information into the sheet.

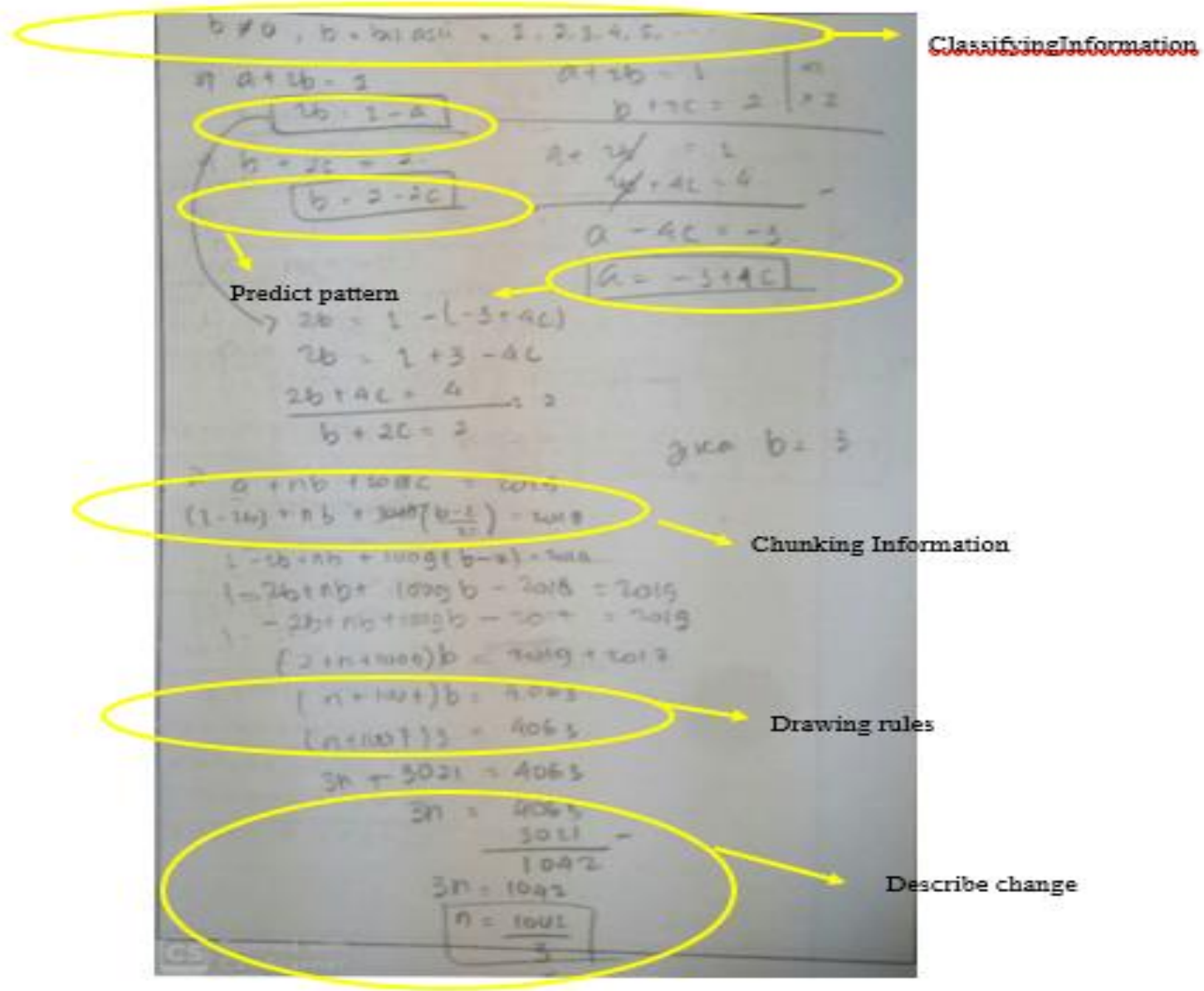

Figure 5. Results of Answer S3 on number 1

S3 subject is able in the process of thinking algebra until the stage of drawing change, the last process is the indicator justifying the rule does not exist. S3 is able in the algebraic thought 
process to the stage of describing the change. To be sure, the researchers interviewed S3 subjects on the results of the HOTS problem-solving.

Q : What about number 1?

S3 : Not bad, Mom

Q : Can you explain how you got the results?

S3 : I use elimination bu and substitution, then because there are still two variables mis $\mathrm{n}$ and $\mathrm{b}$ then $\mathrm{I}$ consider $\mathrm{b}$ is 3

Q : Why do you consider $b$ to be 3? From where?

S3 : For example, ma'am

Q : Then how many results?

S3 : The result is broken fraction, 1042/3 bu

$\mathrm{P} \quad$ : Try whether the results are true if $\mathrm{n}$ is that much?

S3 : different mom

Based on the results of the interview, S3 could not prove the rules that can be obtained, so it can be said that an error in solving the problem by assuming that b is 3 is true, this is in accordance with the statement (Naseer, 2015) which states that Student errors on variables can occur due to the use of teaching materials and methods that are not appropriate during the learning process. Meanwhile, the results of the completion of S4 are presented in Figure 6.

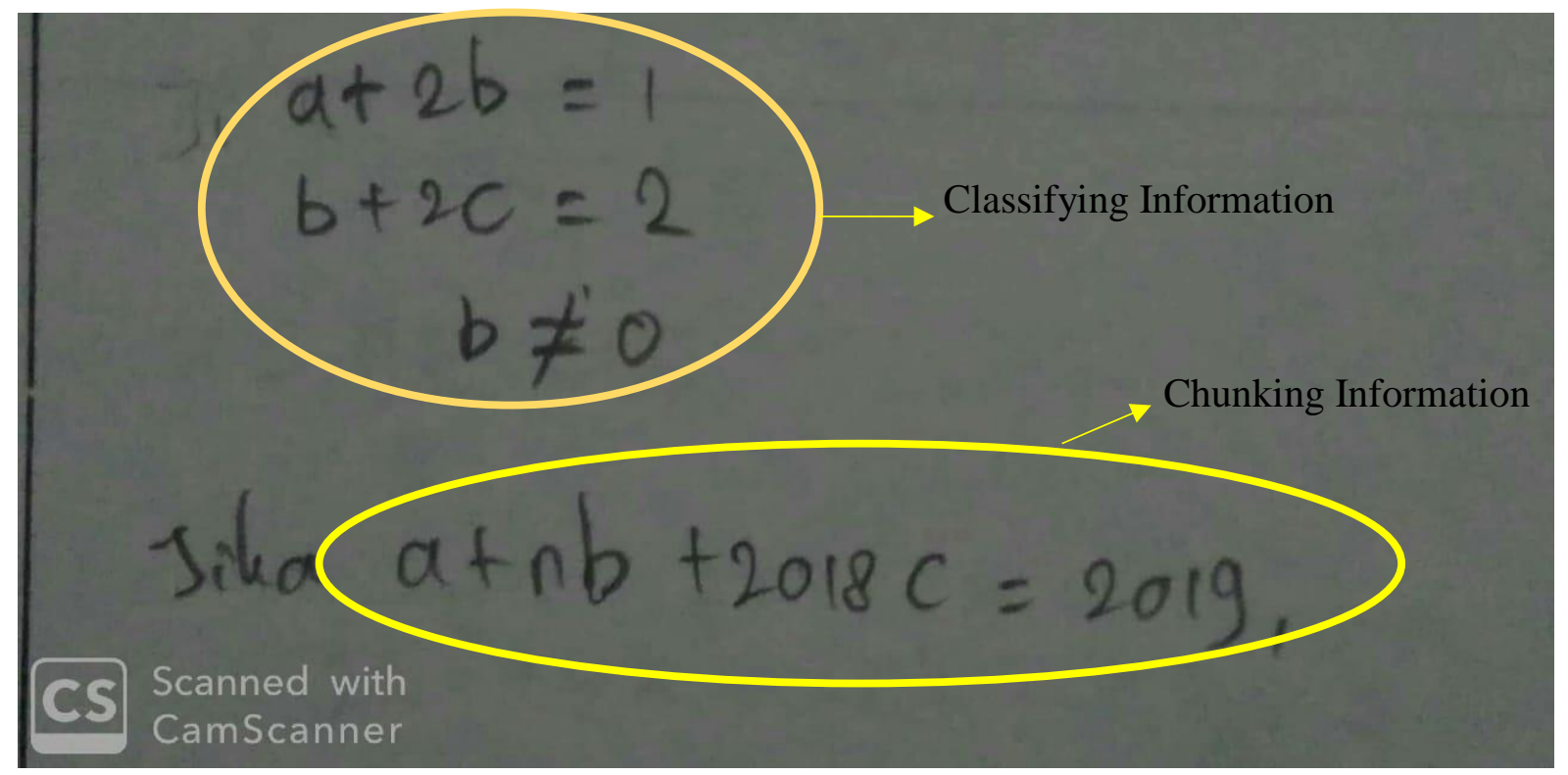

Figure 6. Results of Answer S4 on number 1

S4 subject is only able to classify information that is writing information that is in the answer sheet, after that the subject gives pieces of information in the form of information that is asked, the next algebraic thought process cannot be completed properly. Based on the results of the interview, S4 subjects also did not know the answers or what to do anymore. It can be said that subject $\mathrm{S} 4$ has an algebraic thinking process that is very lacking because it cannot complete until the indicators justify the rules. In accordance with research by (Abidin, 2012) that the causes of student errors occur in completing problems are: Students cannot memorize the 
formula to be used, are inaccurate, inaccurate in answering, there is no preparation for the test, no longer remember how to solve the problem form and not enough time to take the test.so to be able to anticipate this there needs to be creativity and innovation from the teacher in learning in the classroom so that students can easily and thoroughly solve HOTS questions properly.

\section{CONCLUSION AND SUGGESTION}

Based on the results of the study, it can be concluded that: subjects who have high achievement motivation namely S1 and S2 have different algebraic thought processes. S1 subject is able in the process of thinking algebra to the indicator stage describing the rules, but the understanding of concepts in algebra material is not well mastered by S1 subjects, causing S1 subjects to be confused in justifying rules. Meanwhile, subject S2 is only capable of algebraic thought process indicators at the information chunking stage, pieces of information, subject S2 is not able to complete HOTS questions until the last indicator on algebraic thinking processes due to ignorance of how to solve the meaning of understanding the material on HOTS problems is not mastered. Subjects who have low achievement motivation also have different algebraic thinking processes, namely subjects S3 and subjects S4. Subject S3 can solve HOTS problems in algebraic thought process indicators up to the stage, however, S3 subject errors by assuming a variable is true so that the results obtained are wrong, but the algebraic thought process in subject S3 successfully approaches the algebraic thought process in the last indicator namely the indicator describe the change. Whereas, subject S4 is only able in the process of thinking algebra on indicators classifying information by writing back to the answer sheet and indicators of information chunking that is notifying pieces of information available.

\section{REFERENCES}

Abidin, Z. (2012). Pendidikan Matematika Fakultas. Zainal Abidin Journal, XIII(1), 183-196.

Andriani, P. (2015). Penalaran Aljabar Dalam Pembelajaran Matematika. Beta - Scandinavian Journal of Business Research, 8(1), 1-15. https://doi.org/10.20414/beta.v8i1.567

Blanton, M. L., \& Kaput, J. J. (2011). Functional Thinking as a Route Into Algebra in the Elementary Grades. In J. Cai \& E. Knuth (Eds.), Early Algebraization A Global Dialogue from Multiple Perspectives (pp. 5-23). Springer.

Booth, J. L., Lange, K. E., Koedinger, K. R., \& Newton, K. J. (2013). Using example problems to improve student learning in algebra: Differentiating between correct and incorrect examples. Learning and Instruction, 25, 24-34.

Cahyaningtyas, Novita, D., \& Toto. (2018). Analisis Proses Berpikir Aljabar. Jurnal Pendidikan Matematika Dan Sains, 6(1), 50-60.

Driscoll, M., Zawojeski, J., Humez, A., Nikula, J., Goldsmith, L., \& Hammerman, J. (2001). The Fostering Algebraic Thinking Toolkit A Guide for Staff Development. (3).

Gais, Z., \& Afriansyah, E. (2017). Analisis Kemampuan Siswa dalam Menyelesaikan Soal Hogh Order Thinking Ditinjau dari Kemampuan Awal Matematis Siswa. Jurnal "Mosharafa," 6(2), 255-266. 
Jupri, A., Drijvers, P., \& van den Heuvel-Panhuizen, M. (2014). Difficulties in initial algebra learning in Indonesia. Mathematics Education Research Journal, 26(4), 683-710.

Kamaei, A., \& Weisani, M. (2013). the Relationship Between Achievement Motivation, Critical Thinking and Creative Thinking With. Indian Journal of Fundamental and Applik Lied Life Science, 3(4), 121-127.

Kamol, N., \& Har, Y. B. (2010). Upper Primary School Students' Algebraic Thinking. Mathematics Education Research Group of Australasia Inc. MERGA33-2010 Shaping The Future of Mathematics Education, (July), 3-7.

Linacre, J.M. (2007). A User's Guide to WINSTEPS. Chicago: Winsteps.com.

Maharaj, A., \& Wagh, V. (2016). Formulating tasks to develop HOTS for first-year calculus based on Brookhart abilities. South African Journal of Science, 112(11-12), 1-6.

Malihatuddarojah, D., \& Prahmana, R. C. I. (2019). Analisis Kesalahan Siswa Dalam Menyelesaikan Permasalahan Operasi Bentuk Aljabar. Jurnal Pendidikan Matematika, 13(1), 1-8.

Naseer, M. S. (2015, September). Analysis of Students' Errors and Misconceptions in preUniversity Mathematics Courses. In Proceedings: First International Conference on Teaching \& Learning (pp. 34-39).

Ojose, B. (2011). Mathematics literacy: are we able to put the mathematics we learn into everyday use? Journal of Mathematics Education, 4(1), 89-100.

Samo, D. D., Darhim, D., \& Kartasasmita, B. (2017). Developing Contextual Mathematical Thinking Learning Model to Enhance Higher-Order Thinking Ability for Middle School $\begin{array}{lllll}\text { Students. International Education } & \text { Studies, } & 10(12), & \end{array}$ https://doi.org/10.5539/ies.v10n12p17

Sarangi, C. (2015). Achievement Motivation of the High School Students : a Case Study Among Different Communities of Goalpara District of Assam. Journal of Education and Practice, 6(19), 140-145.

Star, J. R., Foegen, A., Larson, M. R., McCallum, W. G., Porath, J., Zbiek, R. M., ... Lyskawa, J. (2015). Teaching Strategies for Improving Algebra Knowledge in Middle and High School Students. Educator's Practice Guide. What Works Clearinghouse.... NCEE 20154010. What Works Clearinghouse.

Sugiyono. (2010). Metode Penelitian Pendidikan Pendekatan Kuantitatif, Kualitatif, dan R\&D. Bandung: Alfabeta.

Taskesen, S. (2019). Investigating the academic motivations and academic achievements of pre-service visual arts teachers*. European Journal of Educational Research, 8(3), 857866. https://doi.org/10.12973/eu-jer.8.3.857 